PERSPECTIVE OPEN

\title{
Carbon dioxide sequestration through silicate degradation and carbon mineralisation: promises and uncertainties
}

\author{
Damien Daval ${ }^{1}$
}

Turning carbon dioxide $\left(\mathrm{CO}_{2}\right)$ into rocks: controlling this process, which naturally operates at the Earth's surface over geological timescales, is likely to represent a major technological challenge of this century. One of the recurring criticisms with the carbonation reactions is their sluggishness, as it is commonly admitted that converting silicates into carbonates within geologic reservoirs may take up to several thousands of years, i.e., a duration which is hardly compatible with the goal of achieving net zero emissions by mid-century. Last year, a study that generated substantial interest suggested that after 2 years, more than $95 \%$ of the $\mathrm{CO}_{2}$ injected over the course of a pilot project of $\mathrm{CO}_{2}$ injection in lava flows in Iceland might have been mineralised into carbonates. While such results could have been considered as a green light for industrial applications, a new high-profile study based on the same pilot experiment tempered this idea, as it revealed unexpected modifications of deep ecosystems in response to $\mathrm{CO}_{2}$ injection, evidencing a bloom of chemolithoautotrophic bacteria, which have the ability to promote autotrophic C-fixation. Stated in other words, part of the $\mathrm{CO}_{2}$ that was initially thought to be mineralised under the form of stable carbonates might instead have been converted into (much more labile) biomass. Assessing the respective contributions of carbonates and biomass to the Csequestration should therefore represent a prerequisite prior to large-scale carbon capture and storage through mineral carbonation, to make sure that the cure is not worse than the disease.

npj Materials Degradation (2018)2:11; doi:10.1038/s41529-018-0035-4

\section{INTRODUCTION}

Mitigating the environmental consequences of the rising levels of anthropogenic $\mathrm{CO}_{2}$ emissions is among the major challenges that the whole mankind will have to face over the course of this century. The Paris agreement (http://unfccc.int/paris_agreement/ items/9485.php) provided a clear roadmap in that respect, with the aim to hold the increase in the global average temperature to "well below $2{ }^{\circ} \mathrm{C}$ above pre-industrial levels", which requires to reach a "net-zero emissions" status.

Reaching this "net-zero emissions" status means that a balance between sources and sinks of greenhouse gases has to be found. While this goal will most likely remain out of reach without a deep restructuring of our economic activities (also known as decarbonisation), it also involves the rapid development of strategies that enable efficient carbon capture, storage, and utilisation. In particular, there has been a growing interest in the development of geologic carbon storage (GCS) facilities, in which pressurised $\mathrm{CO}_{2}$ is injected into rock formations buried up to hundreds of metres below the Earth's surface. Currently, a dozen of large-scale GCS plants are in operation all over the world. ${ }^{1}$ In most of them, $\mathrm{CO}_{2}$ is either used to enhance oil recovery from oil fields (for which the long-term fate of sequestered $\mathrm{CO}_{2}$ is not the main concern), or injected into deep saline formations, where the safety of carbon storage is based on solubility trapping into the formation waters. Although clearly necessary, the main limitations of these two $\mathrm{CO}_{2}$ sequestration methods reside in the limited characteristic storage time that they can offer, which may be of a few hundreds of years in the worst case scenario. ${ }^{2}$ In that respect, it is frequently argued that in situ $\mathrm{CO}_{2}$ sequestration through mineral trapping represents the safest option to store carbon permanently $^{3}$ (Fig. 1a), while representing carbon storage capacities that exceed the amount of fossil carbon that can be burnt using up all oxygen available in air. ${ }^{2}$ The corresponding process of carbon storage is better known as "carbonation".

\section{TURNING SILICATES INTO CARBONATES: THE CARBONATION REACTION}

The carbonation reaction results from the chemical degradation of silicates to make up carbonates. It usually requires the release of divalent cations $\left(\mathrm{Me}^{2+}\right)$, such as $\mathrm{Ca}^{2+}, \mathrm{Mg}^{2+}$, and $\mathrm{Fe}^{2+}$, which are supplied by silicate dissolution:

$$
\mathrm{Me}_{x} \mathrm{SiO}_{2+x}+2 x \mathrm{CO}_{2}+x \mathrm{H}_{2} \mathrm{O} \rightarrow x \mathrm{Me}^{2+}+2 x \mathrm{HCO}^{3-}+\mathrm{SiO}_{2} \text {. }
$$

When saturation with respect to carbonate minerals is reached, their precipitation becomes thermodynamically possible:

$$
x \mathrm{Me}^{2+}+2 x \mathrm{HCO}^{3-} \rightarrow x \mathrm{MeCO}_{3}+x \mathrm{CO}_{2}+x \mathrm{H}_{2} \mathrm{O} \text {. }
$$

The sum of reactions ( 1 ) and (2) leads to the so-called carbonation reaction, in which silicates are eventually turned into carbonate minerals at circum-neutral $\mathrm{pH}$ :

$\mathrm{Me}_{x} \mathrm{SiO}_{2+x}+x \mathrm{CO}_{2} \rightarrow x \mathrm{MeCO}_{3}+\mathrm{SiO}_{2}$.

As the efficiency of the carbonation reaction depends on the release of divalent cation, the typical geological formations targeted to store $\mathrm{CO}_{2}$ by mineral trapping are basalts and ultramafic rocks, which contain elevated amounts of $\mathrm{Me}^{2+}$-bearing materials. $^{4}$

\footnotetext{
'Laboratoire d'Hydrologie et de Géochimie de Strasbourg, EOST/ENGEES, Université de Strasbourg, CNRS UMR 7517, 1 Rue Blessig, 67084 Strasbourg, France Correspondence: Damien Daval (ddaval@unistra.fr)
}

Received: 14 December 2017 Revised: 28 February 2018 Accepted: 1 March 2018

Published online: 04 April 2018 

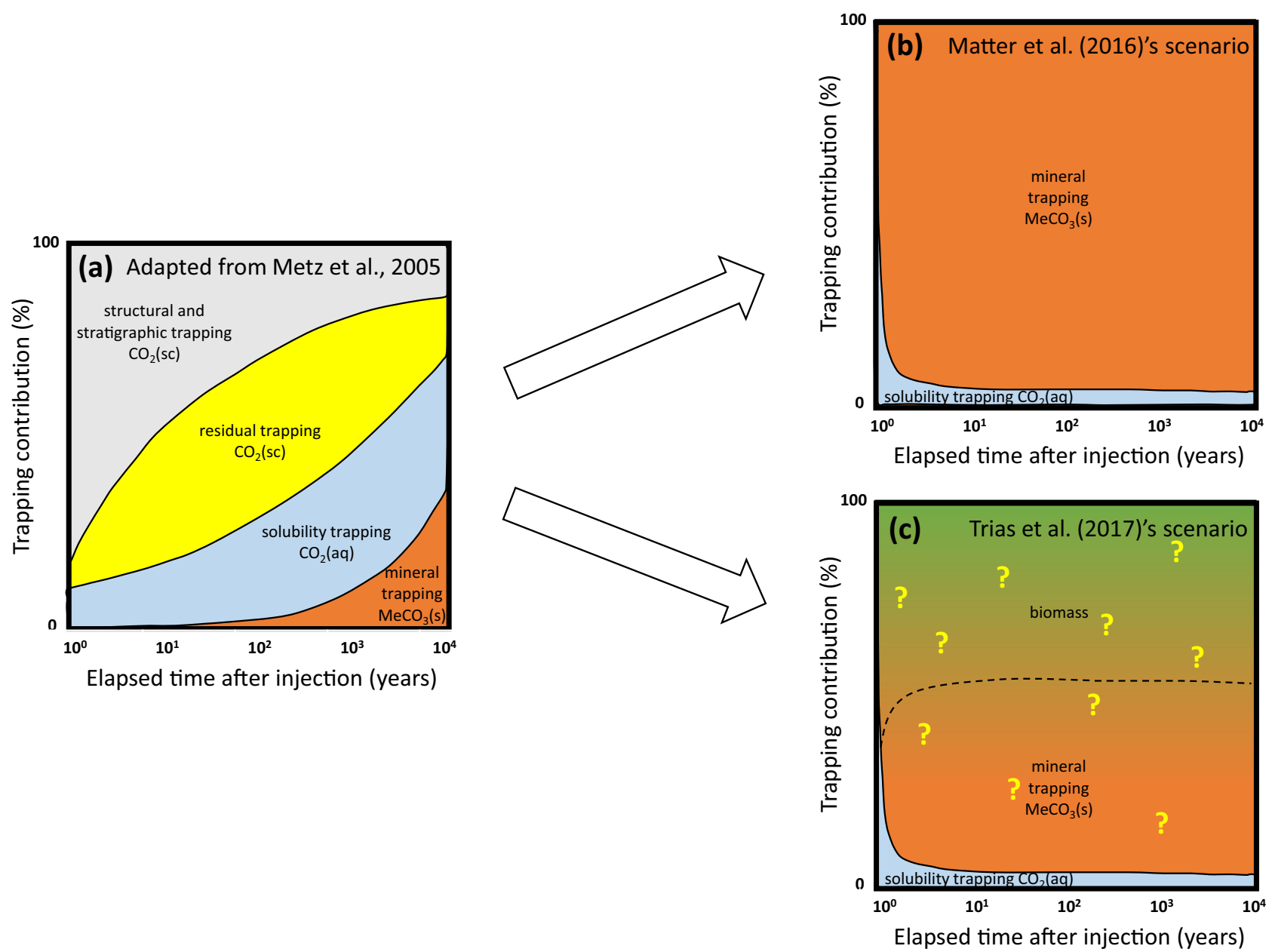

Fig. 1 Fate of injected $\mathrm{CO}_{2}$ into a given geological formation following various scenarios. a Corresponds to the classical view, adapted from Metz et al. ${ }^{3} \mathrm{CO}_{2}$ is injected underground either in a liquid or supercritical state, where it is primarily trapped below a very-low-permeability geological layer, such as shale or salt belts (i.e., "structural and stratigraphic trapping"). As the plume of $\mathrm{CO}_{2}$ migrates underground, it slowly dissolves in water formations, where it is stored as carbonic acid $\left(\mathrm{H}_{2} \mathrm{CO}_{3}\right.$ or $\left.\mathrm{CO}_{2}(\mathrm{aq})\right)$. The acidification of the groundwater promotes the dissolution of the rock-forming minerals and the increase of alkalinity (Eq. (1)), so that the $\mathrm{CO}_{2}$ is then partitioned between residual $\mathrm{CO}_{2}$ (i.e., "residual trapping") and dissolved $\mathrm{CO}_{2}$ (solubility trapping). Eventually, when saturation with respect to carbonates is reached, carbonate mineral may start to precipitate (i.e., "mineral trapping"). This latter mechanism, which is often considered to be the safest option to store $\mathrm{CO}_{2}$ permanently (since the residence time of $C$ in carbonates exceeds $10^{4}$ years ${ }^{2}$ ), is expected to occur a few years after the injection, and its contribution to $\mathrm{CO}_{2}$ trapping becomes significant only $10^{3}-10^{4}$ years after the injection. $\mathbf{b}$ Depicts the fate of $\mathrm{CO}_{2}$ that one can expect based on the data and interpretation of Matter et al.'s study. ${ }^{9}$ In the CarbFix project, the $\mathrm{CO}_{2}$ is dissolved into down-flowing water in the well during its injection. Since $\mathrm{CO}_{2}$ is no longer buoyant, the contribution of structural and stratigraphic trappings becomes non-existent, preventing the migration and escape of $\mathrm{CO}_{2}$. According to Matter et al.'s interpretation of the data, $95 \%$ of the $\mathrm{CO}_{2}$ may trapped as carbonates in 2 years, and $\mathrm{CO}_{2}$ sequestration in basalt formations can be considered to be safe. In $\mathbf{c}$, the same pilot experiment is revisited in light of the data collected by Trias et al., ${ }^{21}$ where part of the $\mathrm{CO}_{2}$ is suggested to be converted into biomass as a result of the bloom of chemolithoautotrophic bacteria that have the ability to promote autotrophic C-fixation. The dashed line represents an arbitrary frontier between the contributions of carbonates and that of biomass to the trapping of $\mathrm{CO}_{2}$. The actual location of this frontier is currently unknown. Similarly, the residence time of $\mathrm{C}$ in biomass also remains essentially unknown

Over the last decade, a significant body of literature was aimed at unravelling the kinetics of this reaction, using various starting silicate materials. The main conclusions of these studies can be conveniently sorted according to the chemical composition of the starting materials: regarding Ca-bearing silicates, it has been demonstrated that the rate-limiting step of the process was the dissolution of silicates, irrespective to the temperature range, ${ }^{5}$ with possible additional contribution of transport limitations into the resulting secondary porous matrix. As for ( $\mathrm{Mg}, \mathrm{Fe}$ )-bearing silicates, deciphering the rate-limiting reaction is far more complex, as it may vary with temperature, ${ }^{6}$ redox conditions, ${ }^{7}$ the saturation state of the solution with respect to amorphous silica, ${ }^{8,9}$ and the complexity of the starting mineralogical assemblage. ${ }^{10} \mathrm{~A}$ common trait of these various studies, however, is that the carbonation reaction is generally slow under the typical conditions of GCS $\left(\leq 90^{\circ} \mathrm{C}\right)$. Based on kinetic rate laws derived from single-mineral dissolution and precipitation experiments, the most optimistic simulations reckon on a sequestration rate on the order of $2 \times 10^{5}$ tons/year $^{11}$ for a typical basaltic reservoir (volume $\sim 20 \mathrm{~km}^{3}$; effective porosity $\sim 10 \%$ ); to be compared with the $\sim 2 \times$ $10^{10}$ tons/year emitted by the top $20 \mathrm{CO}_{2}$-emitting countries. ${ }^{12}$ In addition if one considers that reactive transport simulations overestimate the actual reactivity of silicates by up to several orders of magnitude, even in the context of simplified experimental set-ups dedicated to $\mathrm{CO}_{2}$-water-rock interactions, ${ }^{8,13}$ and taking into account the possible decrease of silicate dissolution rate with time, ${ }^{14}$ any detractor of GCS technology may argue that this process would contribute only negligibly to the aim to reach a 
"net-zero emissions" status by mid-century. In this context of uncertainties, resorting to pilot-scale injection monitoring appears as one of the necessary endeavours to assess the actual efficiency of GCS sites to permanently trap $\mathrm{CO}_{2}$ over timescales as short as a couple of decades.

\section{EVIDENCE FOR $\mathrm{CO}_{2}$ IMMOBILISATION FROM PILOT INJECTION PROJECTS}

While $\mathrm{CO}_{2}$-water-(ultra)mafic rocks interactions have been investigated experimentally for more than a decade, ${ }^{15-17}$ the collection of data from actual field pilot injection projects is still ongoing, and the very first results have just been published this last couple of years. For now, most results remain qualitative, aimed at deciphering whether carbonates did precipitate over the course of the injection. In that respect, McGrail et al. ${ }^{18}$ provided one of the first direct evidence for in situ precipitation of carbonates, by demonstrating that ankerite $\left(\mathrm{Ca}(\mathrm{Fe}, \mathrm{Mg}, \mathrm{Mn})\left(\mathrm{CO}_{3}\right)_{2}\right)$ had formed in vesicles throughout cores that were recovered after the injection of 1000 tons of supercritical $\mathrm{CO}_{2}$ into a basalt formation, in the framework of the Wallula Basalt Pilot Project located in eastern Washington (USA).

Last year, the first quantitative results from the injection of $\mathrm{CO}_{2}$ into a basalt formation were provided in the framework of the CarbFix project (Iceland). ${ }^{19}$ In this pilot injection project, the $\mathrm{CO}_{2}$ is transported from the Hellisheidi geothermal power plant (which emits $\sim 40,000$ tons/year of $\mathrm{CO}_{2}$ of volcanic origin as a by-product of the geothermal energy production ${ }^{11}$ ) in a $3-\mathrm{km}$ pipeline, and dissolved in water in the well during its injection into a basaltic reservoir located at between 400 and $800-m$ depth. Two injection tests were performed in 2012, using either 73 tons of pure $\mathrm{CO}_{2}$ or a $\mathrm{CO}_{2}-\mathrm{H}_{2} \mathrm{~S}$ mixture, containing 55 tons of $\mathrm{CO}_{2}$. For both tests, the $\mathrm{CO}_{2}$ was spiked with ${ }^{14} \mathrm{C}$, and injected together with conservative tracers. Matter et al. ${ }^{19}$ reported results of the geochemical evolution of groundwater collected from a monitoring well located $70 \mathrm{~m}$ downstream from the injection well at 400-m depth below the surface over $\sim 2$-year period. Using simple mass balance calculations, Matter et al. ${ }^{19}$ concluded that over $95 \%$ of the injected $\mathrm{CO}_{2}$ was immobilised between the injection and the monitoring wells, which they attributed to carbonate precipitation. This conclusion was indirectly supported by thermodynamic calculations, which confirmed that the formation waters were supersaturated with respect to calcite over the course of the monitoring, and by the ${ }^{14} \mathrm{C}$ concentration of calcite collected from a submersible pump hauled from the monitoring well, which was similar to that of the injected $\mathrm{CO}_{2}$.

Because $\mathrm{CO}_{2}$ immobilisation in a basaltic formation was then suggested to be massive, at temperature as low as $20-50{ }^{\circ} \mathrm{C}$, in timeframes as short as a couple of years (i.e., even faster than expected from reactive transport simulations ${ }^{11}$ ( $\sim 10$ years), which were yet suspected to provide a lower bound for the time required to sequester $\mathrm{CO}_{2}$ ), these results clearly seemed to open up a new era: from a pure construct of the mind, $\mathrm{CO}_{2}$ mineralisation becomes effective, on timescales compatible with the urgency to remove the $\mathrm{CO}_{2}$ in excess from the atmosphere (Fig. 1b). One may still argue that this estimation was not based on a direct quantification of the mineralogical composition of solid samples before and after the injection; notwithstanding, over $95 \%$ of the $\mathrm{CO}_{2}$ was missing in the recovered fluid samples, meaning that it had to be trapped somewhere. And from an abiotic perspective, carbonate precipitation is by far the most likely mechanism that could account for such an observation.

\section{THE ROLE OF DEEP BIOTA ON C-SEQUESTRATION: AN OVERLOOKED CONTRIBUTION?}

The above-mentioned conclusions even lead one of the Science editors to summarise the exciting findings of Matter et al. ${ }^{19}$ through the enthusiastic title: "Inject, baby, inject!". ${ }^{20}$ However, as detailed below, a subsequent paper $^{21}$ provided a radically different light on the missing $\mathrm{CO}_{2}$ evidenced in the groundwater sampled in the monitoring well of the Hellisheidi pilot plant. Unlike the overwhelming majority of studies dedicated to the fate of interactions between $\mathrm{CO}_{2}$-charged water and (ultra)mafic rocks, which focus exclusively on abiotic processes, Trias et al. ${ }^{21}$ undertook a detailed analysis of the response of deep microbial ecosystems to the $\mathrm{CO}_{2}$ injections described in the previous section. In particular, they investigated the phylogenetic diversity and abundances along with metabolic potential in sampled waters by bacterial 16S-rRNA gene 454-pyrosequencing, metagenomics, and quantitative PCR detection of key genes involved in inorganic carbon assimilation.

Although the presence of a deep microbial biosphere has been acknowledged for a couple of decades, ${ }^{22}$ it must be emphasised that until Trias et al.'s study, ${ }^{21}$ the knowledge of the quantitative contribution of reservoir biota to the C-sequestration, and more generally, to silicate weathering, is in its infancy. The few existing laboratory experiments aimed at deciphering the response of microbial communities to $\mathrm{CO}_{2}$ exposure in the context of $\mathrm{CO}_{2}$ sequestration suggest that elevated $\mathrm{CO}_{2}$ pressure may be responsible for a lethal stress and decrease of the bacterial biomass. $^{23}$ However, there is also growing evidence that in nutrient-poor environments, microbial communities that are specific to each type of rock-forming mineral develop at the mineral surface (also known as "mineralosphere"), harbouring microorganisms with efficient mineral weathering ability. ${ }^{24}$ In addition, few studies dedicated to investigating the changes in microbial communities after $\mathrm{CO}_{2}$ injection in sedimentary basins evidenced rapid modifications in the microbial patterns, with the potential to enhance chemolithoautotrophic activities. ${ }^{25}$ These rapid changes are key in the biogeochemical cycles of many elements, including $C$, as over short-time periods, they are likely to prevail over much slower abiotic geochemical responses. Trias et al. ${ }^{21}$ reported data that perfectly illustrate the versatility of microorganisms when submitted to a perturbation as dramatic as an oxidative and acidifying injection of $\mathrm{CO}_{2}$ : only 2 months after the onset of the injection, when the inorganic carbon concentration reached its highest values in the monitoring well, the bacterial biomass increased by a factor of 500, and the relative proportion of the Gallionellaceae family, which belongs to Betaproteobacteria, became dominant, accounting for $40 \%$ of the 16S-rRNA gene sequences retrieved by metagenomic analysis, whereas these betaproteobacteria represented less than $1 \%$ of the pyrosequences before injection. This result could have been considered as anecdotal, if all members of Gallionellaceae family cultivated so far were not chemolithoautotrophic bacteria, hence representing an increased potential of the microbial community for autotrophic C-fixation. Stated in other words, such bacteria likely contributed to the $\mathrm{CO}_{2}$ conversion into biomass, possibly contributing to the puzzling trapping of $95 \%$ of $\mathrm{CO}_{2}$ over durations as short as 2 years (Fig. 1c). Although the direct confirmation of C-fixation (for instance, through the analysis of the ${ }^{14} \mathrm{C}$ concentration of microbes) was out of reach of this study, these findings have the potential to completely change the picture: the lifetime, the thermodynamic stability, and the mobility of a microbe have nothing in common with those of a mineral. And as far as I know, no comprehensive modelling efforts of $\mathrm{CO}_{2}$ sequestration had been run integrating scenarios where biota would be the primary driver of the $\mathrm{CO}_{2}$ drawdown (in case biota would actually be the primary driver of $\mathrm{CO}_{2}$ drawdown, which is impossible to decipher from Trias et al.'s analyses, as they miss the biomass attached to rocks and the lateral expansion of the $\mathrm{CO}_{2}$ plume). Whatever it be, the study by Trias et al. ${ }^{21}$ is an invitation to reconsider both our strategy to monitor and model the fate of $\mathrm{CO}_{2}$ in low temperature basaltic and ultramafic formations where life can develop $\left(<120^{\circ} \mathrm{C}\right)$, as well as to question our strongest certainties regarding $\mathrm{CO}_{2}$ sequestration. 


\section{SUMMARY AND CONCLUSIONS}

The most recent findings regarding $\mathrm{CO}_{2}$ sequestration through carbon mineralisation in basalt and/or ultramafic formations highlighted the following three main conclusions:

(i) In addition to numerical simulations and laboratory experiments, resorting to pilot-scale injections with increased efforts of monitoring, sampling, and post-mortem characterisation appears as a necessary critical step prior to any larger-scale injection. As opposed to what could have been expected on the sole basis of laboratory experiments and numerical simulations, the injection of $\mathrm{CO}_{2}$ in basalts represents a highly dynamic system (even at low temperature and over short-time durations). Field-scale monitoring helps to determine the dominant processes to which we should pay attention.

(ii) Microbiologists have long been aware of the high potential of bacteria for representing valuable indicators of perturbations in natural settings, such as aquifers or soils. ${ }^{26}$ This knowledge has to permeate the materials and Earth science communities working on $\mathrm{CO}_{2}$ sequestration. Future monitoring studies at the pilot scale should systematically integrate investigations dealing with microbial ecology such as metagenomics/proteomics analyses, and possibly isotope labelling to decipher the amount of biomass that is directly made of injected $\mathrm{CO}_{2}$. The key issue that remains unresolved after the studies of Matter et al. ${ }^{19}$ and Trias et al. ${ }^{21}$ is the relative contribution of biomass and carbonates to $\mathrm{C}$ sequestration. This quantification is required to solve whether carbon sequestration into basalts can be considered as a safe and permanent mean to dispose $\mathrm{CO}_{2}$.

(iii) From both thermodynamic and hydrodynamic standpoints, the fate and localisation of biota are much less predictable than that of carbonates. If future studies confirm that microbial communities present in the storage formations use $\mathrm{CO}_{2}$ as a source of $\mathrm{C}$ to develop, modelling efforts should be directed to integrate microbes as a driver of $\mathrm{C}$-sequestration. On the same footing, because the bloom of microorganisms evidenced in Trias et al.'s study ${ }^{21}$ consists of iron-oxidising bacteria, their effect on silicate degradation (and therefore on the whole carbonation rate) has to be properly taken into account in our modelling strategy, as $\mathrm{Fe}$ (III) has a detrimental role on the dissolution kinetics of silicates typical of basalts and ultramafic rocks. For instance, the dissolution rate of olivine can be reduced by more than two orders of magnitude because of the development of passivating $\mathrm{Fe}(\mathrm{III}) / \mathrm{Si}$-rich surface layers.,

Overall, these recent studies highlight that the now famous sketch of Metz et al. ${ }^{3}$ of storage security with time (Fig. 1) needs to be updated before massive amounts of $\mathrm{CO}_{2}$ can be confidently injected into basalt formations.

\section{ACKNOWLEDGEMENTS}

The author is grateful to B. Ménez (IPGP, France) for stimulating discussions, and to two anonymous reviewers, whose comments and suggestions improved the present article.

\section{AUTHOR CONTRIBUTIONS}

D.D. wrote the manuscript.

\section{ADDITIONAL INFORMATION}

Competing interests: The author declares no competing financial interests.

Publisher's note: Springer Nature remains neutral with regard to jurisdictional claims in published maps and institutional affiliations.

\section{REFERENCES}

1. Global CCS Institute. The Global Status of CCS: Summary Report (Global CCS Institute, Australia, 2016)
2. Lackner, K. S. A guide to $\mathrm{CO}_{2}$ sequestration. Science 300, 1677-1678 (2003).

3. IPCC. in IPCC Special Report on Carbon Dioxide Capture and Storage. Prepared by Working Group III of the Intergovernmental Panel on Climate Change (eds Metz, B., Davidson, O., de Coninck, H.C., Loos, M. \& Meyer, L.A.) 442 (Cambridge University Press, Cambridge, New York, 2005).

4. Oelkers, E. H., Gislason, S. R. \& Matter, J. Mineral carbonation of $\mathrm{CO}_{2}$. Elements 4 , 333-337 (2008).

5. Daval, D. et al. Carbonation of Ca-bearing silicates, the case of wollastonite: experimental investigations and kinetic modeling. Chem. Geol. 265, 63-78 (2009).

6. Saldi, G. D., Daval, D., Morvan, G. \& Knauss, K. G. The role of Fe and redox conditions in olivine carbonation rates: an experimental study of the rate limiting reactions at 90 and $150^{\circ} \mathrm{C}$ in open and closed systems. Geochim. Cosmochim. Acta 118, 157-183 (2013)

7. Saldi, G. D. et al. Mineralogical evolution of Fe-Si-rich layers at the olivine-water interface during carbonation reactions. Am. Mineral. 100, 2655-2669 (2015).

8. Daval, D. et al. Influence of amorphous silica layer formation on the dissolution rate of olivine at 90 degrees C and elevated pCO(2). Chem. Geol. 284, 193-209 (2011).

9. Johnson, N. C. et al. Olivine dissolution and carbonation under conditions relevant for in situ carbon storage. Chem. Geol. 373, 93-105 (2014).

10. Sissmann, O. et al. Enhanced olivine carbonation within a basalt as compared to single-phase experiments: reevaluating the potential of $\mathrm{CO}_{2}$ mineral sequestration. Environ. Sci. Technol. 48, 5512-5519 (2014).

11. Aradóttir, E., Sonnenthal, E., Björnsson, G. \& Jónsson, H. Multidimensional reactive transport modeling of $\mathrm{CO}_{2}$ mineral sequestration in basalts at the Hellisheidi geothermal field, Iceland. Int. J. Greenh. Gas Con. 9, 24-40 (2012).

12. Oelkers, E. H. \& Cole, D. R. Carbon dioxide sequestration a solution to a global problem. Elements 4, 305-310 (2008).

13. Galeczka, I., Wolff-Boenisch, D., Oelkers, E. H. \& Gislason, S. R. An experimental study of basaltic glass $-\mathrm{H}_{2} \mathrm{O}-\mathrm{CO}_{2}$ interaction at 22 and $50^{\circ} \mathrm{C}$ : implications for subsurface storage of $\mathrm{CO}_{2}$. Geochim. Cosmochim. Acta 126, 123-145 (2014).

14. Zhang, S. \& DePaolo, D. J. Rates of $\mathrm{CO}_{2}$ mineralization in geological carbon storage. Acc. Chem. Res. 50, 2075-2084 (2017).

15. Giammar, D. E., Bruant, R. G. \& Peters, C. A. Forsterite dissolution and magnesite precipitation at conditions relevant for deep saline aquifer storage and sequestration of carbon dioxide. Chem. Geol. 217, 257-276 (2005)

16. Huijgen, W. J. J., Witkamp, G.-J. \& Comans, R. N. J. Mechanisms of aqueous wollastonite carbonation as a possible $\mathrm{CO}_{2}$ sequestration process. Chem. Eng. Sci. 61, 4242-4251 (2006).

17. McGrail, P. B., Schaef, T. H., Ho, A. M., Chien, Y.-J. \& Dooley, J. J. Potential for carbon dioxide sequestration in flood basalts. J. Geophys. Res. 111, B12201 (2006).

18. McGrail, B. P. et al. Field validation of supercritical $\mathrm{CO}_{2}$ reactivity with basalts. Environ. Sci. Technol. Lett. 4, 6-10 (2017).

19. Matter, J. M. et al. Rapid carbon mineralization for permanent disposal of anthropogenic carbon dioxide emissions. Science 352, 1312-1314 (2016).

20. Smith, H. J. Inject, baby, inject! Science 352, 1288-1288 (2016).

21. Trias, R. et al. High reactivity of deep biota under anthropogenic $\mathrm{CO}_{2}$ injection into basalt. Nat. Commun. 8, 1063 (2017).

22. Fredrickson, J. K. \& Balkwill, D. L. Geomicrobial processes and biodiversity in the deep terrestrial subsurface. Geomicrobiol. J. 23, 345-356 (2006).

23. Gulliver, D. M., Lowry, G. V. \& Gregory, K. B. Comparative study of effects of $\mathrm{CO}_{2}$ concentration and $\mathrm{pH}$ on microbial communities from a saline aquifer, a depleted oil reservoir, and a freshwater aquifer. Environ. Eng. Sci. 33, 806-816 (2016).

24. Uroz, S. et al. Minerals affect the specific diversity of forest soil bacterial communities. Geomicrobiol. J. 29, 88-98 (2011).

25. O'Mullan, G. et al. Microbial stimulation and succession following a test well injection simulating $\mathrm{CO}_{2}$ leakage into a shallow newark basin aquifer. PLOS ONE 10, e0117812 (2015)

26. Imfeld, G. \& Vuilleumier, S. Measuring the effects of pesticides on bacterial communities in soil: a critical review. Eur. J. Soil Biol. 49, 22-30 (2012).

\footnotetext{
Open Access This article is licensed under a Creative Commons Attribution 4.0 International License, which permits use, sharing, adaptation, distribution and reproduction in any medium or format, as long as you give appropriate credit to the original author(s) and the source, provide a link to the Creative Commons license, and indicate if changes were made. The images or other third party material in this article are included in the article's Creative Commons license, unless indicated otherwise in a credit line to the material. If material is not included in the article's Creative Commons license and your intended use is not permitted by statutory regulation or exceeds the permitted use, you will need to obtain permission directly from the copyright holder. To view a copy of this license, visit http://creativecommons. org/licenses/by/4.0/.
}

(c) The Author(s) 2018 